\title{
Yield and nutrient status of wheat plants (Triticum aestivum) as affected by sludge, compost, and biofertilizers under newly reclaimed soil
}

\author{
Manal F. Mohamed, Alice T. Thalooth ${ }^{*}$ (D) Tarek A. Elewa and Amal G. Ahmed
}

\begin{abstract}
Background: Two field experiments were carried out during the two successive winter seasons of 2012-2013 and 2013-2014 in Research and Production Station, National Research Centre, Al-Nubaria District, Al-Behaira Governorate, Egypt. This work was carried out to study the effect of sludge and compost application combined with biofertilizers on yield and yield components as well as nutrient content of grains.

Results: The obtained results showed that either sludge or compost as organic fertilizers increased most yield parameters, i.e., spike length, weight of spike, and number and weight of grains per spike. Grain and straw yield as well as biological yield ton/faddan increased by either sludge or compost as compared with chemical fertilizers. Nutrient uptake of wheat grain increased also by both fertilizer and dual application with either sludge or compost with biofertilizers.

Conclusion: From the obtained results, it was revealed that application of compost or sludge with either "azotobacter" or yeast as biofertilizers has superior promoting effect on yield and yield components as well as nutrient content of the grains than chemical fertilizers. Thus, it can be recommended to substitute chemical fertilization by these organic and biofertilizers to obtain high productivity of wheat.
\end{abstract}

Keywords: Sludge, Compost, Azotobacter, Yeast, Wheat yield, Nutrient uptake

\section{Background}

It is well known that the conciliation of performance improvement of wheat crops depends on maintaining the stock of nutrients in soil, which is essential for plant growth. As reported by Tilman et al. (2002), the global use of nitrogen $(\mathrm{N})$ and phosphorus fertilizers increased by 7 - and 3.5-fold, respectively, in the past six decades; both fertilizers are expected to increase further threefold by 2050 . Moreover, the abundant use of fertilizers also increases the risk of pollution. In addition, due to high cost of mineral fertilizers and escalating trends in their prices, there is an increasing trend of using organic fertilizers such as sewage sludge and compost in agriculture, especially in arid and semi-arid regions of the

\footnotetext{
* Correspondence: thaloothadel@yahoo.com

Field Crop Research Department, National Research Center, El-Behouth Street Dokki, Giza, Egypt
}

\section{Springer Open}

(c) The Author(s). 2019 Open Access This article is distributed under the terms of the Creative Commons Attribution 4.0 International License (http://creativecommons.org/licenses/by/4.0/), which permits unrestricted use, distribution, and reproduction in any medium, provided you give appropriate credit to the original author(s) and the source, provide a link to the Creative Commons license, and indicate if changes were made. may be sustainable and economical.

In this regard, several studies have shown that sewage sludge, by their richness in organic matter, improves the mineral and water statuses of soil and therefore increases crop production (Lobo et al. 2013). The application of sewage sludge (SS) to agricultural land can improve soil fertility and physical properties and enhance crop production (Marinari et al. 2000). Recently, sludge application in agriculiure has been suggested to be used as ecofriend fertilizer (Singh and Agrawal 2010).

Composting also could be an efficient, cost-effective, and environmentally safe biological process for the recycling of residual agricultural biomasses (Pane et al. 2015). Multiple benefits drived from compost using as fertilizer by increasing organic content and microbal activity (Scotti et al. 2015). A great concentration of plant nutrients like 
$\mathrm{N}, \mathrm{P}, \mathrm{K}$ and $\mathrm{Mg}$ resulted from compost application (Donn et al. 2014).

Furthermore, besides the use of composting municipal solid wastes and sewage sludge in agriculture, the use of biological fertilizers today is considered to limit the use of mineral fertilizers (Arafa Rawhia et al. 2009). Application of biofertilizers decreases agricultural costs, maximizing crop yield due to providing them with an available nutritive elements and growth promoting substances (Metin et al. 2010 and Ahmed et al. 2011).

In these field experiments, we study the integrated effect of organic fertilizers in combination with biofertilizers as compared with chemical fertilizers on yield and nutrient content of wheat grown in sandy soil.

\section{Material and methods}

Two field experiments were carried out at the Research and Production Station, National Research Centre, Al-Emam Malek Village, Nubaria District Al-Behaira Governorate, Egypt, 2012-2013 and 2013-2014 winter seasons. The objective of the trail was to investigate the effect of sludge or compost as a source of organic fertilizers in combination with biofertilizers (azotobacter or yeast and their combination) on the yield of wheat grown in sandy soil. The experimental soil was analyzed according to the method described by Jackson (1973). Mechanical and chemical analyses of the experimental soil are presented in Table 1).

Each experiment includes nine treatments in three replicates which were control (NPK fertilizer) with the recommended dose, sludge application which is the activated type of municipal sewage sludge, sludge application and inoculation with azotobacter (bio 1), sludge application and inoculation with yeast (bio2), sludge application and inoculation with both azotobacter and yeast (bio1 + bio2), compost application which is produced by treatment of plant residue sludge, compost application and inoculation with azotobacter (bio1), compost application and inoculation with yeast (bio2), and compost application and inoculation with both azotobacter and yeast (bio1 + bio2). The chemical analysis of sludge and compost is shown in Table 2 .

Table 1 Mechanical and chemical analyses of the experimental soil (2012-2013 and 2013-2014 seasons)

\begin{tabular}{llll}
\hline Mechanical analysis & \multicolumn{3}{c}{ Chemical analysis } \\
\hline Sand \% & 912 & Organic matter \% & 0.3 \\
Silt \% & 4.0 & EC mmhos $/ \mathrm{cm}^{3}$ & 0.3 \\
Clay \% & 4.8 & $\mathrm{pH}$ & 7.4 \\
CaCO3 \% & 1.3 & Soluble N ppm & 7.7 \\
Soil texture & Sandy & Available P ppm & 2.9 \\
& & Exchange K ppm & 19.8 \\
\hline
\end{tabular}

Table 2 Chemical compounds of compost and sludge

\begin{tabular}{|c|c|c|c|}
\hline \multicolumn{2}{|l|}{ Compost } & \multicolumn{2}{|l|}{ Sludge } \\
\hline Contents & Units & Contents & Units \\
\hline Nitrogen $(\mathrm{N})$ & $1.32 \%$ & Nitrogen (N) & $2.52 \%$ \\
\hline Phosphorus (P) & $0.33 \%$ & Phosphorus (P) & $0.36 \%$ \\
\hline Potassium (K) & $0.60 \%$ & Potassium (K) & $0.18 \%$ \\
\hline Calcium (Ca) & $3.32 \%$ & Ferrus (Fe) & $1.27 \%$ \\
\hline Magnesium (Mg) & $0.28 \%$ & Manganese (Mn) & $319 \mathrm{mg} / \mathrm{kg}$ ds \\
\hline Sodium (Na) & $0.65 \mathrm{mg}$ & Zinc (Zn) & $1410 \mathrm{mg} / \mathrm{kg} \mathrm{ds}$ \\
\hline Zinc (Zn) & $1780 \mathrm{mg}$ & Cupper (Cu) & $315 \mathrm{mg} / \mathrm{kg}$ ds \\
\hline Copper (Cu) & $380 \mathrm{mg}$ & Chromium (Cr) & $426 \mathrm{mg} / \mathrm{kg} \mathrm{ds}$ \\
\hline Rubidium (Rb) & $450 \mathrm{mg}$ & Lead (Pb) & $360 \mathrm{mg} / \mathrm{kg}$ ds \\
\hline \multirow[t]{2}{*}{ Cadmium (Cd) } & $5.8 \mathrm{mg}$ & Cadium (Cd) & $3.77 \mathrm{mg} / \mathrm{kg} \mathrm{ds}$ \\
\hline & & Nickel (Ni) & $140 \mathrm{mg} / \mathrm{kg} \mathrm{ds}$ \\
\hline
\end{tabular}

The experimental design was a complete block design with three replicates. The plot size was $10.5 \mathrm{~m}^{2}=1 / 400$ fed. Grains of wheat (Triticum aestivum c,v. Sakha-93) were sown in 15 November in both winter seasons. NPK fertilizer was added with the recommended dose. Municipal sewage sludge from Giza (Abu Rawash Station) and composted municipal solid waste (CMSW) were mixed with the biofertilizer types (azotobacter and yeast) as presented in the experiment treatments and were applied during soil preparation at the rate of $10 \mathrm{~m}^{3} / \mathrm{fed}$. Agricultural practices of growing wheat were practiced until harvest as recommended.

At harvest time, wheat plants were collected and the following characters were determined: plant height, length and weight per spike, weight of grains per spike, grain weight per spike, number of grains per spike, grain yield per faddan $\left(\right.$ faddan $=4200 \mathrm{~m}^{2}$ ), straw yield per faddan, biological yield per faddan, and weight of 1000 grains. Representative samples from ground grains were taken to determine the following nutrient constituents: $\mathrm{N}, \mathrm{P}, \mathrm{K}, \mathrm{Fe}, \mathrm{Ca}, \mathrm{Mg}, \mathrm{Mn}, \mathrm{Zn}$, and Cu. Macro- and micronutrients were extracted using the dry ashing digestion method according to Chapman and Pratt (1961). Total nitrogen content was determined using the method described by A.O.A.C.(1985). Phosphorus was determined calorimetrically according to the method described by Jackson (1973). Micronutrients and Mg were measured using atomic absorption spectrophotometer (PerkinElmer 100 B). Potassium and calcium were measured in the digested suspension using the flame photometer (Eppendorf, DR Lang), according to the methods described by Chapman and Pratt (1961).

Statistical analysis was performed according to Snedecor and Cochran (1990), and the combined analysis of the two-season results was conducted. Treatment means were compared by LSD test at $5 \%$. 


\section{Results}

Effect of sludge and compost and biofertilizers on wheat yield

\section{Yield and yield components}

Regarding the effect of sludge and compost on yield and yield components, the data presented in Table 3 revealed that sludge significantly increased most yield and yield components, i.e., spike length, weight of spike, and number and weight of grains per spike. Grain yield as well as straw yield ton per faddan and consequently biological yield also showed high record as compared with chemical fertilizers. In this respect, Koutroubas et al. (2014) reported that the application of solid sludge resulted in tall plants with high dry matter than those obtained with chemical fertilizers. Several investigators also showed the enhanced effect of sludge on yield and yield components. In this concern, Ozyazici (2013) and Koutroubas et al. (2014) reported that both straw and grain yield increased with increasing rates of sewage sludge application up to $40 \mathrm{t} \mathrm{ha}^{-1}$.

The same table (Table 3) also showed that application of compost induced similar trend of sludge application but compost fertilizer recorded higher values as compared with sludge ones. Regarding plant length, Nadjet et al. (2014) recorded that the maximal length of stems is revealed by substrates containing compost. The enhanced effect of compost on yield and yield components is recorded by Hafidi et al. (2012) who have shown an increase in the seed yield of wheat cultivar in comparison with the control by using $12.8 \mathrm{~kg}$ of compost. Nadjet et al. (2014) also added that compost resulted in best-marked developments of wheat plants and better yield in number of seeds, weight of seeds, number of spikes, and their weights than the control. They also reported that such effect may be due to their high contents of mineral elements and it can be more interesting to increase the amount of compost for better increase of wheat yield.

Regarding the weight of 1000 grain, the data show that either sludge or compost application increased this criterion as compared with chemical application. Similar results are obtained by Hafidi et al. (2012) and Dhir (2016) by sludge application. Sefidkoohi et al. (2012) and Nadjet et al. (2014) also reported that the highest amount of 1000 kernel weight was observed in $40 \mathrm{t} / \mathrm{ha}$ of compost treatment.

The interaction effect of biofertilizers with sludge and compost on yield and yield components of wheat is presented in Table 3. The obtained results revealed that combined application of sludge with either azotobacter or yeast greatly increased most yield characters as compared with single application of sludge. Grain yield as well straw yield was positively affected by the dual application with either azotobacter or yeast. However, the combined application with sludge and both azotobacter and yeast together has less promoting effect on yield and yield components.

Concerning the interaction effect of compost with biofertilizers, the same table (Table 3) showed that combined application with either azotobacter or yeast has promoting effect on most studied yield criterion but the effect of azotobacter was more pronounced than yeast. Grain yield and straw yield ton/faddan and consequently biological yield were also greatly affected by dual application of compost with azotobacter or yeast, but mixed application of both biofertilizers has less effect than when used single with compost. These results confirmed the findings obtained by Mahara et al. (2000) and Samya et al. (2009). In this concern, Afifi et al.

Table 3 Effect of compost, sludge, and biofertilizers on yield and yield components of wheat plants grown in newly reclaimed soil

\begin{tabular}{|c|c|c|c|c|c|c|c|c|c|c|}
\hline Treatment & $\begin{array}{l}\text { Plant } \\
\text { length } \\
(\mathrm{cm})\end{array}$ & $\begin{array}{l}\text { Spike } \\
\text { length (cm) }\end{array}$ & $\begin{array}{l}\text { Wt. of } \\
\text { spike }(g)\end{array}$ & $\begin{array}{l}\text { Wt. of grains } \\
\text { (g/spike) }\end{array}$ & $\begin{array}{l}\text { Grain no. } \\
\text { per spike }\end{array}$ & $\begin{array}{l}\text { Grain yield } \\
\text { (t/fed) }\end{array}$ & $\begin{array}{l}\text { Bio. yield } \\
\text { (t/fed) }\end{array}$ & $\begin{array}{l}\text { Straw yield } \\
\text { (t/fed) }\end{array}$ & $\begin{array}{l}\text { Harvest } \\
\text { index }\end{array}$ & $\begin{array}{l}\text { Wt. of } 1000 \\
\text { grains }(\mathrm{g})\end{array}$ \\
\hline Sludge & 76.67 & 10 & 1.77 & 1.62 & 36.66 & 1.12 & 3.44 & 2.32 & 32.56 & 36.3 \\
\hline Sludge + bio 1 & 79.67 & 9.67 & 2.02 & 1.8 & 41.22 & 1.45 & 5.17 & 3.72 & 28.05 & 38.5 \\
\hline Sludge + bio 2 & 78.00 & 10.33 & 2.31 & 2.4 & 44.16 & 1.29 & 4.74 & 3.45 & 27.22 & 37.47 \\
\hline $\begin{array}{l}\text { Sludge }+ \text { bio } 1 \\
+ \text { bio } 2\end{array}$ & 78.33 & 9.33 & 1.95 & 1.69 & 41.20 & 1.16 & 4.46 & 3.3 & 26.01 & 37.67 \\
\hline Compost & 77.33 & 9 & 2.3 & 1.85 & 39.10 & 1.16 & 3.51 & 2.35 & 33.05 & 46.17 \\
\hline $\begin{array}{l}\text { Compost }+ \text { bio } \\
1\end{array}$ & 77.33 & 9.33 & 2.38 & 2.4 & 46.61 & 1.68 & 4.03 & 3.88 & 41.69 & 43.2 \\
\hline $\begin{array}{l}\text { Compost }+ \text { bio } \\
2\end{array}$ & 75.30 & 9.33 & 2.73 & 2.2 & 47.00 & 1.41 & 5 & 3.59 & 28.20 & 40.33 \\
\hline $\begin{array}{l}\text { Compost }+ \text { bio } \\
1+\text { bio } 2\end{array}$ & 79.33 & 8.67 & 2.34 & 1.94 & 42.44 & 1.28 & 4.46 & 3.18 & 28.70 & 40.17 \\
\hline Mineral fertilizer & 74.00 & 9.67 & 2.08 & 1.64 & 36.11 & 1.06 & 3.27 & 2.21 & 32.42 & 39.67 \\
\hline LSD & 0.61 & 1.41 & 0.14 & 0.12 & 2.68 & 0.06 & 0.10 & 0.09 & 1.36 & 1.52 \\
\hline
\end{tabular}


(2014) indicated that biofertilizer addition to either sludge or compost organic fertilizers led to plant growth enhancing and gave increments of most studied characteristic values. The positive effects of yeast are also recorded by Ali et al.(2013) who reported that application of yeast significantly increased all growth criteria and grain and straw yield and yield components of wheat.

\section{Effect on nutrient content}

The effect of sludge, compost, and biofertilizers on nutrient content of wheat grain is illustrated in Table 4 . Concerning sludge effect, the obtained results revealed that sludge application induced higher nutrient content of most elements as compared with mineral fertilization. Such promoting effect of sludge on nutrient uptake is confirmed by the findings obtained by Warman and Termeer (2005) and Vacai Rocio et al. (2011). Regarding compost effect on nutrient uptake by wheat grains, the data presented in the same table (Table 4) showed that compost application also induced enhancing effect on most studied nutrients (NPK and $\mathrm{Ca}, \mathrm{Mg}, \mathrm{Na}, \mathrm{Fe}, \mathrm{Mn}$, $\mathrm{Zn}$, and $\mathrm{Cu}$ ) as compared with chemical fertilization. These results supported the views of Akbarinia et al. (2003) who showed that increasing municipal compost application increased the concentration of $\mathrm{Fe}, \mathrm{Zn}$, and $\mathrm{Cu}$ in the plant. Soumare et al. (2003) also added that using $50 \mathrm{t} / \mathrm{ha}$ of compost leads to higher levels of nutrient absorption in the plant.

However, the positive effect of both sludge and compost was reported also by Warman and Termeer (2005) who found that sewage sludge and sludge compost applications to corn produced the highest $\mathrm{Ca}$ and $\mathrm{Zn}$ and sludge produced the highest corn Mn.

The interaction effects of either sludge or compost with the biological fertilizer azotobacter and yeast and their mixture are also illustrated in Table 3. Mean comparisons showed that the dual application of sludge with either azotobacter or yeast increased most nutrient uptake of wheat grains. Such effect was more pronounced with azotobacter application and less effect with the mixed one of azotobacter and yeast. The same trend was also observed with the united application of compost with azotobacter or yeast or their mixture. These results are associated with the finding recorded by Alaleh Mottaghian et al. (2008) and Khattab et al. (2015) who found that yeast significantly increased protein, nitrogen, phosphorus, potassium, magnesium, ferric, and zinc.

\section{Discussion}

From the obtained results, it is clearly shown that sludge increased most yield and yield components, i.e., spike length, weight of spike, number and weight of grains per spike, grain yield, and biological yield. Such promoting effect of sludge may be attributed to its effect on increasing avalability and content of nutrients such as nitrogen, phosphorus and potassium in the soil and in turn promoting growth and yield productivity (Dhir, 2016). These results were in agreement with those obtained by Ozyazici (2013) and Koutroubas et al. (2014).

The obtained results also showed that compost application induce promoting effect on yield and yield components of wheat. The enhancement effect of compost may be resulted from a greater concentration of plant nutrients like $\mathrm{N}, \mathrm{P}, \mathrm{K}$, and $\mathrm{Mg}$ and a root reinforcement induced by compost (Donn et al. 2014 and Nadjet et al. 2014). Similar results are obtained by Hafidi et al. (2012) and Lakhdar et al. (2014) who reported that biomass production of treated plants with $100 \mathrm{t} / \mathrm{ha}$ compost significantly increased by $78 \%$ relative to the control.

Concerning the effect of combined application of sludge and compost with either azotobacter or yeast increased yield and yield components than single application, but the mixed application of both biofertilizers have less effect. Such promoting effect of the dual application of sludge or compost with either azotobacter or yeast might be due to the ability of the azotobacter bacteria to release some chemical compounds that stimulate growth hormones like cytokinins, indoleacetic acid, and gibberellins (Ahmed et al.1995 and Glick 1995). Yeast

Table 4 Effect of compost, sludge, and biofertilizers on nutrient content of grain of wheat plants grown in newly reclaimed soil

\begin{tabular}{|c|c|c|c|c|c|c|c|c|c|c|}
\hline Treatment & Total N & $\mathrm{P}(\%)$ & K (\%) & Ca (\%) & $\mathrm{Mg}(\%)$ & $\mathrm{Na}(\%)$ & $\mathrm{Fe}(\mathrm{ppm})$ & Mn (ppm) & Zn (ppm) & Cu (ppm) \\
\hline Sludge & 1.28 & 0.40 & 0.506 & 0.018 & 0.21 & 0.013 & 194.00 & 12.0 & 107.00 & 13.5 \\
\hline Sludge + bio 1 & 1.29 & 0.50 & 0.782 & 0.022 & 0.23 & 0.018 & 256.00 & 18.5 & 185.00 & 21.0 \\
\hline Sludge + bio 2 & 1.29 & 0.49 & 0.655 & 0.017 & 0.38 & 0.014 & 197.50 & 16.0 & 189.00 & 15.5 \\
\hline Sludge + bio $1+$ bio 2 & 1.21 & 0.43 & 0.54 & 0.016 & 0.25 & 0.013 & 174.00 & 13.0 & 161.00 & 15.0 \\
\hline Compost & 1.42 & 0.52 & 0.483 & 0.016 & 0.24 & 0.012 & 164.00 & 11.0 & 103.50 & 11.0 \\
\hline Compost + bio 1 & 1.50 & 0.57 & 0.586 & 0.021 & 0.26 & 0.014 & 295.50 & 13.5 & 121.50 & 17.5 \\
\hline Compost + bio 2 & 1.57 & 0.56 & 0.529 & 0.017 & 0.25 & 0.015 & 201.50 & 13.5 & 111.50 & 15.5 \\
\hline Compost + bio $1+$ bio 2 & 1.25 & 0.51 & 0.506 & 0.015 & 0.18 & 0.012 & 168.00 & 12.0 & 112.50 & 14.5 \\
\hline Mineral fertilizer & 1.18 & 0.35 & 0.379 & 0.013 & 0.20 & 0.008 & 151.00 & 11.0 & 94.50 & 12.5 \\
\hline
\end{tabular}


also improves the environment of plant roots because of the development of the yeast after its analysis into wide groups of amino acids and vitamins (Ali et al. 2013).

As for the effect of sludge compost on the nutrient content of wheat grain, this study showed that either sludge or compost increased the nutrient content of grain. Such effect resulted from the higher nutrient content of most elements of sludge and compost and their ability to improve the availability of nutrients (Vacai Rocio et al. 2011). The dual application of sludge or compost with either azotobacter or yeast increased most nutrient uptake of wheat grains. Such effect resulted from the ability of biofertilizer to increase protein, nitrogen, phosphorus, potassium, magnesium, ferric, and zinc (Alaleh Mottaghian et al. 2008 and Khattab et al. 2015). These results were in agreement with the finding of Zaghloul et al. (2010) who reported that the highest records of NPK uptake appeared with the dual application of biofertilization and organic manuring.

\section{Conclusion}

On the basis of above results, it can be concluded that the dual application of sludge or compost with either azotobacter or yeast had great effect on yield and yield components as well as macronutrient uptake of wheat grains. Thus, it can be recommended to substitute chemical fertilization to provide high productivity of wheat, obtain plant safety, and reduce the environmental pollution.

\section{Abbreviation}

Bio 1: Azotobacter; Bio 2: Yeast

\section{Acknowledgements}

The authors would like to thank Research and Production Station, National Research centre, AL-Emam Malek village, Nubaria District team for their facilitates during this work.

\section{Funding}

The work was self-funded by the authors.

Availability of data and materials

The datasets supporting the results are included within the article.

\section{Authors' contributions}

All authors have contributed significantly to the conception and design of the study, the interpretation of data, and the drafting and revision of the manuscript. All authors read and approved the final manuscript.

\section{Ethics approval and consent to participate}

The authors declare that the work is ethically approved and consent to participate.

\section{Consent for publication}

The authors declare that the work has a consent for publication.

\section{Competing interests}

The authors declare that they have no competing interests.

\section{Publisher's Note}

Springer Nature remains neutral with regard to jurisdictional claims in published maps and institutional affiliations.

Received: 6 November 2018 Accepted: 8 February 2019

Published online: 18 February 2019

\section{References}

A L, lannelli MA, Debez A, Massacci A, Jedidi N, Abdelly C (2014) Effect of municipal solid waste compost and sewage sludge use on wheat (Triticum durum): growth, heavy metal accumulation, and antioxidant activity. J Sci Food Agric 90(6):965-971

A.O.A.C (1985) Official methods of analysis of the official analytical chemists. 14 ed, Washington, D.C

Afifi MH, Khalifa RKM, Khattab EA, Camilia YE-D (2014) Response of two flax cultivars to different sources of organic and bio fertilizers addition under newly reclaimed sandy soil conditions. Middle East j Agric Res 3(2):311-317

Ahmed FF, Regab MMA, Gobara AA, Mansour AEM (1995) The beneficial of supplying active dry yeast to some nutrients foliage spraying for Anna apple trees (Malus domestica) symposium on foliar fertilization a technique to improve productivity and decrease pollution, Cairo. Egypt

Ahmed MA, Amal GA, Magda HM, Tawfik MM (2011) Integrated effect of organic and biofertilizers on wheat productivity in new reclaimed sandy soil. Res J Agric \& Biol Sci 7(1):105-114

Akbarinia A, Ghalavand A, Sharifi Ashorabadi A, Banj Shfieei S (2003) Effect of different nutrition systems on soil propertis, elemental uptake and seed yield of Ajowan (Carum Cupticum). Pajouhesh and sazandegi 62:11-29

Arafa Rawhia AM, AbdEl-Ghany F, Bouthaina Sidkey M, Elshazly MM (2009) The beneficial use of biofertilizers on growth and yield of wheat plants grown on sandy soil with or without nitrogen fertilization. Egypt J Biotechnol 32:127-146

Chapman HO, Pratt PE (1961) Methods of analysis for soil, plants and waters. University of California, Division of Agricultural Sciences, p 309

Dhir B (2016) Municipal sludge: an effective soil supplement for improving plant growth. Ind J Plant Physiol 21:213

Donn S, Wheatley RE, McKenzie BM, Loades KW, Hallett PD (2014) Improved soil fertility from compost amendment increases root growth and reinforcement of surface soil on slope. Ecol Eng 71:458-465

El-Hosary AA, Hammam GY, El-Morsi A, Hassan EA, El-Awadi ME, Abdel-Baky YR (2013) Effect of some bio-regulators on growth and yield of some wheat varieties under newly cultivated land conditions. Science and Nature 2(3):75-83

Glick BR (1995) The enhancement of plant growth by free living bacteria. Cand JMicrobiology 41:109-117

Hafidi M, Amir S, Meddich A, Jouraiphy A, Winterton P, El Gharous M, Duponnois R (2012) Impact of applying composted biosolids on wheat growth and yield parameters on a calcimagnesic soil in a semi-arid region. Afr J Biotechnol 11(41):9805-9815

Jackson ML (1973) Soil chemical analysis. Prentice- Hall Inc, N.J., USA

Khattab EA, Camilia Y, El-Dewiny MH, Afifi and R. Kh. M. Khalifa (2015) Response of some varieties of faba bean to yeast and algae and their impact on yield and its components, Middle East. Journal of Agriculture Research 4:907-913

Koutroubas SD, Antoniadis V, Fotiadis S (2014) Growth, grain yield and nitrogen use efficiency of Mediterranean wheat in soils amended with municipal sewage sludge. Nutr Cycl Agroecosyst 100:227-243

Lobo TF, Grassi Filho H, Bull LT, Moreira LLQ (2013) Management of sewage sludge and mineral nitrogen in soil fertility over time. Semin Ciênc Agrár 4:2705-2725

Mahara G, Sandera V, Jaime B, Partricia M (2000) Isolation of enterobacteria, azotobacter and pseudomonas sp. producers of IAA and siderophores from Colombian rice rhizosphere. Rev. Amer. J Microbiol 42:171-176

Marinari S, Masciandaro G, Ceccanti B, Grego S (2000) Influence of organic and mineral fertilisers on soil biological and physical properties. Bioresour Technol 72:9-17

Metin TA, Medine GB, Ramazan CC, Taskin OF, Sahin D (2010) The effect of PGPR strain on wheat yield and quality parameters. Proceeding of World Congress of Soil Science, Soil Solutions for a Changing World.1 - 6 August 2010, Brisbane, Australia

Nadjet M, Abderezzak D, Meriem KH (2014) Effect of three types of composts of olive oil by-products on growth and yield of hard wheat "Triticum durum Desf.". Afr J Biotechnol 13(52):4685-4693

Ozyazici MA (2013) Effects of sewage sludge on the yield of plants in the rotation system of wheat-white head cabbage-tomato. Eurasian Journal of Soil Science 2:35-44 
Pane C, Celano G, Piccolo A, Villecco D, Spaccini R, Palese M, Zaccardelli M (2015) Effects of on-farm composted tomato residues on soil biological activity and yields in a tomato cropping system. Chem Biol Technol Agric 2:4

Pirdashti AMH, Bahmanyar MA, Abbasian A (2008) Leaf and seed micronutrient accumulation in soybean cultivars in response to integrated organic and chemical fertilizers application. Pak J Biol Sci 11(9):1227-1233

Rocio V, Jorge L, Ricardo M, María EV, Hilda Z (2011) Effect of sewage sludge and sewage sludge compost amendment on soil properties and Zea mays $L$, plants (heavy metals, quality and productivity). Rev Int Contam Ambie 27(4):303-311

Samya EH, Omran E, Mohamed Al, Amal HE-G (2009) Influence of organic and biofertilization on productivity, viability and chemical components of flax seeds. Egypt J Soil Sci 49(1):4964

Scotti R, Ascoli DR, Bonanomi G, Caceres MG, Sultana S, Cozzolino L, Scelza R, Zoina A, Rao MA (2015) Combined use of compost and wood scraps to increase carbon stock and improve soil quality in intensive farming systems. Eur. J Soil Sci. https://doi.org/10.1111/ejss.12248

Sefidkoohi AA, Sepanlou GM, Bahmanyar MA (2012) Investigating the effects of long-term application of compost-like output on wheat yield and N, P and K in kernel and soil under planting. Afr J Agric Res 7(14):2215-2224

Singh RP, Agrawal M (2010) Effect of different sewage sludge applications on growth and yield of Vigna radiata L. field crop: metal uptake by plant. Ecol Eng 36:969

Snedecor GW, Cochran WG (1990) Statistical methods 8th Ed. In: lowa State Univ. Press Ames, lowa, USA

Soumare M, Tach FMG, Verloo MG (2003) Effect of municipal solid waste compost and mineral fertilization on plant growth in two tropical agricultural soils in Mali. Bioresour Techenol 88:15-20

Tilman D, Cassman KG, Matson PA, Naylor R, Polasky S (2002) Agricultural sustainability and intensive production practices. Nature 418:671-677

Warman PR, Termeer WC (2005) Evaluation of sewage sludge, septic waste and sludge compost applications to corn and forage: $\mathrm{Ca}, \mathrm{Mg}, \mathrm{S}, \mathrm{Fe}, \mathrm{Mn}, \mathrm{Cu}, \mathrm{Zn}$ and $\mathrm{B}$ content of crops and soils. Bioresour Technol 96:1029-1038

Zaghloul RA, El-Husseiny TM, Hanafy EA, AGH R, Abdelrahman HM (2010) Effect of biofertilization and organic manuring on soil dehydrogenase activity, macro nutrients and essential oil content of marjoram. Egypt J Microbiol Special Issue"13th Conf of Microbiol":15-32

\section{Submit your manuscript to a SpringerOpen ${ }^{\circ}$ journal and benefit from:}

- Convenient online submission

- Rigorous peer review

- Open access: articles freely available online

- High visibility within the field

- Retaining the copyright to your article

Submit your next manuscript at $\boldsymbol{\nabla}$ springeropen.com 